\title{
Spatial pattern of a fish assemblage in a seasonal tropical wetland: effects of habitat, herbaceous plant biomass, water depth, and distance from species sources
}

\author{
Izaias M. Fernandes ${ }^{1}$, Francisco A. Machado² and Jerry Penha ${ }^{3}$
}

The influence of habitat, biomass of herbaceous vegetation, depth and distance from permanent water bodies on the structure of fish assemblages of a seasonal floodplain was evaluated using data collected along 22 transects in an area of $25 \mathrm{~km}^{2}$ in the floodplain of Cuiabá River, Pantanal, Brazil. Each transect was sampled for fish using throw traps and gillnets during the flood period of 2006. Multivariate multiple regression analysis and multivariate analysis of covariance indicated that depth was the only variable that affected the structure of the fish assemblage, both for quantitative data (abundance) and qualitative data (presence-absence). Species such as Neofundulus parvipinnis and Laetacara dorsigera were more abundant in shallower sites (below $25 \mathrm{~cm}$ ), while Serrasalmus maculatus and Metynnis mola were found mostly in the deepest areas (over $55 \mathrm{~cm}$ ). However, species such as Hoplias malabaricus and Hoplerythrinus unitaeniatus occurred at all sampled depths. Although the distribution of most species was restricted to a few sites, there was a positive relationship between species richness and depth of the water body. Surprisingly, the replacement of native vegetation by exotic pasture did not affect the fish assemblage in the area, at the probability level considered.

A influência do habitat, biomassa de vegetação herbácea, da profundidade e da distância de corpos d'água permanentes sobre a estrutura da assembleia de peixes da planície sazonalmente inundada foi avaliada com dados coletados em 22 transectos em uma área de $25 \mathrm{~km}^{2}$ na planície de inundação do rio Cuiabá, Pantanal. Cada transecto foi amostrado para peixes usando "throw trap" e rede de espera no período de cheia de 2006. Análises de regressão múltipla multivariada e análises de covariância multivariada indicaram que a profundidade foi a única das variáveis consideradas no estudo que afetou a estrutura da assembleia de peixes, tanto para os dados quantitativos (abundância) quanto para os dados qualitativos (presença-ausência). Espécies como Neofundulus parvipinnis e Laetacara dorsigera foram mais abundantes em locais mais rasos (abaixo de $25 \mathrm{~cm}$ ), enquanto as espécies Serrasalmus maculatus e Metynnis mola foram encontradas principalmente nos locais mais profundos (acima de $55 \mathrm{~cm}$ ). Entretanto espécies como Hoplias malabaricus e Hoplerythrinus unitaeniatus ocorreram em todas as profundidades amostradas. Apesar de grande parte das espécies apresentarem distribuição restrita a poucos locais, houve uma relação positiva entre a riqueza de espécies e a profundidade do corpo d'água. Surpreendentemente, no nível de probabilidade considerado, a substituição da vegetação nativa por pastagens exóticas não afetou a assembleia de peixes na área estudada.

Key words: Assemblage structure, Effect of habitat alteration, Floodplain, Species richness, Temporary water.

\section{Introduction}

The floodplain of large rivers is an environmental mosaic that includes permanent lotic environments (rivers), lentic environments (lakes) and temporary water bodies. These temporary water bodies are formed by the expansion of the littoral zone of the permanent water bodies during each new flood cycle (Junk et al., 1989; Ward et al., 2002). The high availability of nutrients in the system during flooding stimulates the rapid growth of microorganisms, invertebrates and aquatic macrophytes, providing food and shelter for species that exploit this environment (Jordan, et al., 1997; Lowe-McConnell, 1999; Penha et al., 1999; Saint-Paul et al., 2000; Agostinho et al., 2001; Li \& Gelwick, 2005). The magnitude and duration of the flood may act in a different way on species that use temporary habitats to complete their

\footnotetext{
${ }^{1}$ Pós-Graduação em Ecologia e Conservação da Biodiversidade, Universidade Federal de Mato Grosso. biomedice@hotmail.com ${ }^{2}$ Núcleo de Estudos Ecológicos do Pantanal, Instituto de Biociências, Universidade Federal de Mato Grosso. ${ }^{3}$ Laboratório de Ecologia de Populações, Instituto de Biociências, Universidade Federal de Mato Grosso, Av. Fernando Correa da Costa s/n, Coxipó, 78060-900 Cuiabá, Mato Grosso, Brazil.
} 
life cycle, thus affecting the species composition of aquatic communities that use the river-plain system (Arrington \& Winemiller, 2003; Petry et al., 2003; Thomaz et al., 2007).

Studies on the structure and dynamics of fish assemblages of permanent water bodies in different floodplain river systems indicate that these assemblages are structured by a combination of environmental variables, such as water transparency, morphometry of the water body and predation pressure exerted by large piscivores (Rodriguez \& Lewis, 1997; TejerinaGarro et al., 1998; Súarez et al., 2001; Hoeinghaus et al., 2003), as well as by the pool of species available during the period in which the water bodies are permanently connected to the river (Súarez et al., 2001; Barko et al., 2006). While most aquatic environments in the floodplain are formed by temporary ponds, little is known about the factors that structure the fish assemblages in this sub-system. The few studies carried out on these temporary systems focus on the structure of the fish assemblages in the temporary ponds, formed during the retraction of the flood. These studies show that the hydroperiod, the depth and the connection with permanent water bodies, or distance from the permanent water bodies, are the main factors that structure the assemblages in these environments (Baber et al., 2002; Pazin et al., 2006).

Similar to other floodplain river systems, the Pantanal floodplain is composed of seasonally flooded habitats and other permanently dry ones, as a result of the subtle variations in topography (Prance \& Schaller, 1982). Among the habitats that undergo seasonal flooding, the ones with different forest types, savannas and grasslands, stand out. However, cattle farming in this system has led to replacement of native vegetation by exotic species, as an alternative to improving animal productivity (Junk, 2000). Many studies show that exotic species can reduce the survival, density, biomass, species richness, diversity and evenness as well ecosystem process in worldwide terrestrial (Hoffmann et al., 2008; Hejda et al., 2009) and aquatic environments (Latini \& Petrere, 2004; Pelicice \& Agostinho, 2009). Thus, the replacement of native vegetation by exotic pasture can affect the structure and dynamics of fish assemblages (Baber et al., 2002) by altering the composition and abundance of native plant species, as well as the hydrological conditions of the landscape. Herein, we investigate the effect of habitat, herbaceous plant biomass, depth of the water column and distance from the species source on the structure of the fish assemblages in a changing seasonal floodplain of the Cuiabá River, in the North Pantanal, Brazil. Our goal is to answer two main questions: (i) which of these environmental variables affect the structure, the composition and the species richness of fish assemblages? (ii) does the replacement of native vegetation by exotic pasture alter the structure, composition and species richness of fish assemblages in this system?

\section{Material and Methods}

\section{Study area}

The Pantanal covers an area of approximately $140.000 \mathrm{~km}^{2}$ and is a mosaic of different habitats that supports a rich aquatic and terrestrial biota. Situated in the Upper Paraguay Basin, in the Central region of South America, between $16^{\circ}$ and $22^{\circ} \mathrm{S}$ and $55^{\circ}$ and $58^{\circ} \mathrm{W}$, it includes parts of the territories of Brazil, Paraguay and Bolivia (Adámoli, 1982).

The vegetation of the region is influenced by four different biomes: Amazonian forest, Cerrado, Chaco and Atlantic Rainforest (Adámoli, 1982). According to the classification of Köppen, the climate of the Pantanal is classified as Tropical Climate - hot and humid - (PCBAP, 1997), hot and wet in the summer, and dry and cold in the winter. The mean annual temperature is $25^{\circ} \mathrm{C}$, and from September to December the absolute maximum temperatures exceed $40^{\circ} \mathrm{C}$. The driest months occur between June and August. Between May and July the temperature is subject to abrupt drops as a result of the cold fronts coming from Antarctica. The mean annual precipitation in the Pantanal varies from 1100 to $1200 \mathrm{~mm}$, with a concentration of rainfall in December, January and February (Adámoli, 1982; Mourão et al., 2002).

Our study was carried out using a Site of Long-Term Sampling (SLTS), situated in the Pantanal de Poconé, State of Mato Grosso, Brazil ( $\left.56^{\circ} 21^{\prime} \mathrm{W}, 56^{\circ} 18^{\prime} \mathrm{E}, 16^{\circ} 19^{\prime} \mathrm{N}, 16^{\circ} 22^{\prime} \mathrm{S}\right)$ (Fig. 1). The area of study changes yearly from an aquatic to terrestrial phase, from three to five months in the aquatic phase, and from seven to nine months in terrestrial one. The SLTS system includes 30 plots of $250 \mathrm{~m}$ systematically distributed throughout an area of $25 \mathrm{~km}^{2}$. The plots have a fixed length but variable width, adaptable to the taxon being studied. For fish, we used the smallest width possible, which in practice transforms the plot into a transect.

The plots follow the topographical level of the land and are located at a minimum distance of $1 \mathrm{~km}$ from each other (Magnusson et al., 2005). Performing samples in units that follow the topography of the land has an important impact when working with aquatic organisms as it minimizes the differences in depth within a plot and maximizes the differences between plots. This variable can then be included in the analysis models.

The SLTS system study design was established in three private properties used for low density cattle ranching - about 16.03 individuals $/ \mathrm{km}^{2}$. The vegetation of the area is influenced mainly by the Cerrado biome and it is typical to find fields with native pasture, fields with exotic pasture and areas with arboreal vegetation, distributed as a mosaic. In the former, the aquatic phase promotes the appearance and increase of species adapted to the presence of water, such as aquatic macrophytes (Junk et al., 1989), and a reduction of species that do not support flooding (Rebellato \& Nunes da Cunha, 2005). The fields with exotic pasture are made up almost exclusively by Brachiaria humidicola (Rendle) Schweick vr. Lanero, a grass species that is resistant to flooding. The sites with arboreal vegetation are dominated mainly by three species: Cambará (Vochysia divergens Pohl.), Landi (Callophyllon brasiliense Gam) and Pimenteira (Licania parvifolia Huber).

\section{Sampling}

Data collection occurred in March 2006 during a flooded period in the area in which 22 of the 30 plots were flooded. We 


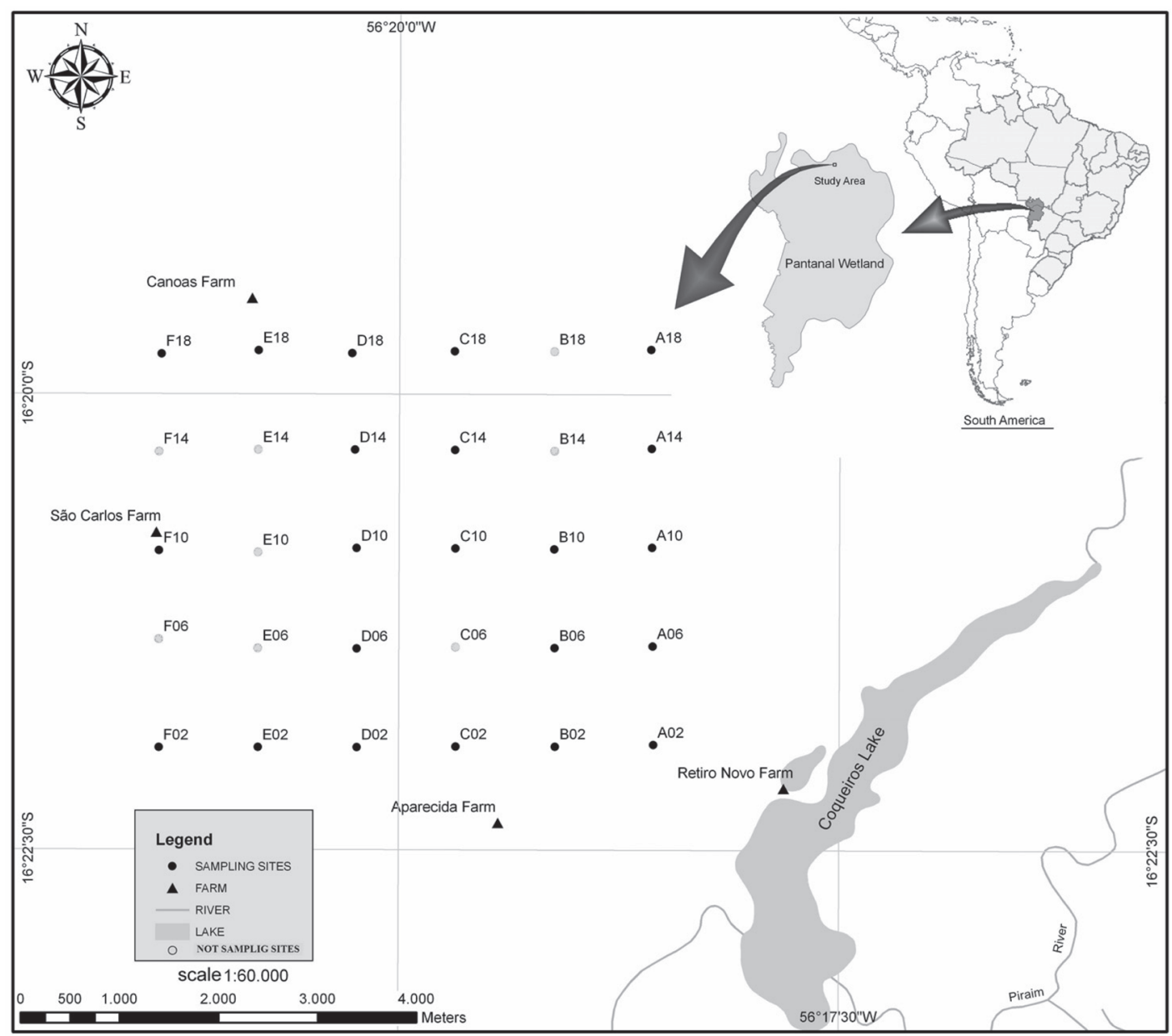

Fig. 1. Geographical location of the study area and the Site of Long-Term Sampling (in the area). The system is installed in the Pantanal, Brazil.

decided to sample in this month - about the middle of the flooded period - because we believe that colonization rates are high during the rising phase and extinction is high during the receding water phase. Hence, in the middle of the period, the colonization and extinction are probably equal and the assemblage is more stable.

Fish were collected using two methods: throw trap (consisting of a cubic metal structure $\left(1 \mathrm{~m}^{3}\right)$ with the four sides covered by a nylon $1.5 \mathrm{~mm}$ mesh) - that is efficient for the collection of individuals up to $100 \mathrm{~mm}$ in length (Jordan et al., 1997; Baber et al., 2002, Pelicice et al., 2005), and gill net efficient for different size classes. These fishing techniques were used on different days, so that one method did not interfere with the efficiency of the other. As the capture efficiency of each equipment varies with the environment sampled, we used a combination of active and passive collection gears, allowing the capture of both mobile and sedentary species, as well as the capture of individuals in different size classes (Weaver et al., 1993; Lapointe et al., 2006). The throw trap was employed every 50 meters, starting at point zero until $250 \mathrm{~m}$, making a total of six launches per plot. The collector slowly approached the predetermined point, waited for about 1 minute until the fish became used to his/her presence, placed the throw trap quickly in the water and then pressed it against the ground. The individuals captured in the trap were collected with the aid of a triangular fish trap that was used until no additional fish was captured after passing it 10 consecutive times through the throw trap. Parallel to each plot, a battery of seven gill nets was distributed (mesh size of $12,15,18,20,25,30$ and $50 \mathrm{~mm}$ between opposite knots), each $20 \mathrm{~m}$ long and $1.5 \mathrm{~m}$ high. As the sampling sites were shallow $(<53 \mathrm{~cm})$ only a portion of the nets remained submerged in the water. The gill nets were positioned at 7:00 hs and removed at 17:00 hs, and inspected at 12:00 hs for removing the captured specimens. Most studies use gill nets for 24 hours, or between 15:00 and 10:00 hours, because fish species are most active at sunset and sunrise. Not many studies compare the community patterns that emerge from diurnal samples compared to nocturnal samples and so it is very difficult to assess the efficiency of our method. However, Teixeira-de-Mello et al. (2009) did not find any differences in the spatial-temporal patterns of fish communities present in submerged macrophytes arising from changes in the sampling shift on lakes in a subtropical and temperate climate. Furthermore, contrary to the expected, the density of fish was higher during the day than at night (Teixeira-de-Mello et al., 2009). 
In our study the decision to restrict the sample to the diurnal period was due to the high predation rate of fish caught in nets by alligators and birds, in addition to logistical limitations (the assembly and review of the nets often involved covering, on foot or on horseback, an area of $25 \mathrm{~km}^{2}$ ).

Captured fish were fixed in 10\% formalin solution and preserved in $70 \%$ ethanol, identified to the species level, and measured for standard length (SL) using digital calipers to $0.01 \mathrm{~mm}$. The identification of each species was made using Britski et al. (1999), and nomenclature follows Reis et al. (2003).

Six depth measurements of the water column were taken at each plot, using a tape measure fixed to a pole, one at each point where the throw trap was launched. The depth of the water column in each plot was represented by the average of the six measurements. The classification of the type of vegetation in each plot was based on the phytophysiognomicalecological system of the Brazilian Institute of Geography and Statistics (IBGE, 1992). The vegetation was classified in three types: fields with native pasture, fields with exotic pasture and arboreal vegetation. Before removing the fish, the herbaceous vegetation within the area bounded by the throw trap was cut at ground level with the aid of a knife to obtain the biomass of the herbaceous vegetation. The grass samples were packed in plastic bags labeled for transport and then transferred to labeled paper containers. In the laboratory, samples were kept in an incubator at $40^{\circ} \mathrm{C}$, until a constant mass was reached, and they were then weighed. The herbaceous biomass in each plot was represented by the average of six samples.

To define the colonization source of species for the plots, the permanent water bodies within and near the SLTS were mapped in October 2008, during the final dry phase (terrestrial phase) in the study area. The permanent water body was considered as a source of species for a plot when no geographical barriers were observed between the two sites. The Euclidean distance between each plot and the closest permanent water body was calculated from the geographical position of the two sites using a GPS (Geographic Positioning System) Garmin Model eTrex Vista ${ }^{\mathrm{TM}}$. We are aware that this distance measure is not the best way to represent distances between locations in a drainage network. However, the drainage system that distributes water from the flooded area of the grid is formed from subtle variations in the elevation of the land, and no secondary channels occur in the area. In this context, any attempt to map these networks is a very difficult task and not free of diagnostic errors. Thus, we chose to use a distance measure with known limitations rather than one which could be misleading.

\section{Statistical analysis}

The plots were ordered using Principal Coordinates Analysis (PCoA) based on the abundance (quantitative) and presence/absence data (qualitative) of the species (Anderson $\&$ Willis, 2003). The quantitative data reveal the assemblage pattern using the most common species as a base, as they tend to have a large quantitative difference between sites. Presence/absence data tend to give more weight to the rare species, since the common species occur in the majority of the sites and, therefore, contribute very little towards the qualitative differences between the sites (Mendonça et al., 2005; Kinupp \& Magnusson, 2005; Costa et al., 2005; Pazin et al., 2006). The association matrix used in the PCoA was constructed using the Bray-Curtis distance, after standardization, dividing the number of individuals of each species in a plot by the total number of individuals found in that plot (Faith et al., 1987). For construction of the association matrix with the presence/absence data, the Sørensen index was used (Legendre \& Legendre, 1998). As the three axes of the PCoA captured more than $50 \%$ of the variation, they were extracted from the analysis and considered to be representative of the strongest pattern in the assemblage and are therefore considered in the subsequent analyses.

A Multivariate Multiple Regression was used to evaluate which environmental variables are responsible for the major variation in the composition of the assemblages. The composition of the species at each site, represented by the three axes of the PCoA, was the response variable and depth, herbaceous biomass, and distance from the species source, were the explanatory variables. In addition, Multiple Linear Regression was used to investigate the effect of the environmental variables on species richness.

A Multivariate Analysis of Covariance (MANCOVA) was used to investigate the effect of exotic pasture introduction on the composition of species in the assemblage. In this analysis, the composition of species in the plots was used as a response variable, depth (the environmental variable selected in the Multivariate Multiple Regression model) was used as the co-variable, and vegetation cover as the factor one. We used the Analysis of Covariance (ANCOVA) to investigate the effect of the vegetation cover on species richness. In this case, depth and herbaceous plant biomass, effective variables in the Multiple Linear Regression model, were used as covariables, and plant cover was used as a factor.

In order to evaluate the possible effect of the collection equipment, all the analysis described above were carried out using combined (throw trap and gill net) and separate (data for throw traps and data for gill nets) data sets. Because the results of the analysis were similar, we only show our analysis for the combined set of data.

\section{Results}

\section{Description of the sampled plots}

Six out of twenty two sampled plots were covered by arboreal vegetation, twelve had native grassland and four had exotic pasture. The depth of the water column in the plots ranged between $5.8 \mathrm{~cm}$ in plot A14 to $52.4 \mathrm{~cm}$ in plot B02, with an average depth of $19.4 \mathrm{~cm}$. The aerial biomass of the herbaceous vegetation varied from 0.005 in plot D10 to $0.366 \mathrm{~g} / \mathrm{m}^{2}$ in plot $\mathrm{C} 02$, with an average of $0.112 \mathrm{~g} / \mathrm{m}^{2}$. Some plots were near permanent water bodies (61 m plot for $\mathrm{C} 02)$, while others were farther away (1518 $\mathrm{m}$ for plot A06) with an average distance of $509 \mathrm{~m}$ (Table 1). 


\section{Ichthyofauna}

We captured 1117 individuals, distributed in six orders, 14 families and 49 species. The order with the highest richness and abundance values was Characiformes, with 27 species (75.83\% of the total number of individuals collected), followed by Perciformes, Siluriformes, Cyprinodontiformes, Gymnotiformes and Synbranchiformes. Most of the species caught were small; the largest individual caught was from the species Leporinus macrocephalus (piavuçu) measuring 340 $\mathrm{mm}$ standard length and the smallest one was from the species Serrapinnus spp. (piquira) measuring $6.8 \mathrm{~mm}$ standard length. The average standard length of specimens captured at SLTS was $51.7 \mathrm{~mm}$ (Table 2).

Of the 49 captured species, seven represented $77 \%$ of all captured individuals. The species with the largest number of individuals were the characids Serrapinnus spp., Hoplerythrinus unitaeniatus, Hyphessobrycon elachys, Pyrrhulina australis and Serrapinnus microdon and the cichlids Cichlasoma dimerus and Laetacara dorsigera. The rest of the 42 captured species each represented less than $4 \%$ of the total number of captured individuals.

\section{Relationship between the ichthyofauna and the environmental variables}

The three PCoA axes captured a large part of the distance variation, both for quantitative (74.2\%) and qualitative (56.6\%) data. Multivariate multiple regression indicated that the composition of species in the assemblage, represented by the three PCoA axes, was only significantly related with water depth (quantitative data: Pillai trace $=0.461, \mathrm{~F}_{3,15}=4.269, \mathrm{p}=0.023$; qualitative data: Pillai trace $=0.663, \mathrm{~F}_{3,15}=9.817, \mathrm{p}=0.001$ ). To illustrate the effect of depth on the distribution of fishes in the

Table 1. Data of biotic and abiotic variables from the 22 collection plots in Site of Long-Term Sampling (SLTS). * Herbaceous plant biomass was not sampled in this plot.

\begin{tabular}{ccccc}
\hline Plots & $\begin{array}{c}\text { Mean } \\
\text { depth }(\mathrm{cm})\end{array}$ & $\begin{array}{c}\text { Herbaceous plant } \\
\text { biomass }\left(\mathrm{g} / \mathrm{m}^{2}\right)\end{array}$ & $\begin{array}{c}\text { Distance from } \\
\text { Colonizing } \\
\text { source }(\mathrm{m})\end{array}$ & Vegetal cover \\
\hline A02 & 33.6 & 0.080 & 1022 & Arboreal \\
A06 & 19.9 & 0.058 & 1518 & Arboreal \\
A10 & 8.2 & 0.059 & 672 & Native grassland \\
A14 & 5.8 & $*$ & 391 & Native grassland \\
A18 & 10.1 & 0.187 & 768 & Native grassland \\
B02 & 52.4 & 0.124 & 363 & Exotic pasture \\
B06 & 33.5 & 0.053 & 101 & Native grassland \\
B10 & 37.7 & 0.058 & 636 & Arboreal \\
C02 & 7.5 & 0.336 & 61 & Exotic pasture \\
C10 & 11.7 & 0.187 & 597 & Native grassland \\
C14 & 8.3 & 0.185 & 708 & Native grassland \\
C18 & 8.0 & 0.128 & 221 & Native grassland \\
D02 & 24.4 & 0.142 & 379 & Exotic pasture \\
D06 & 32.8 & 0.113 & 148 & Exotic pasture \\
D10 & 22.9 & 0.005 & 202 & Arboreal \\
D14 & 12.6 & 0.082 & 832 & Arboreal \\
D18 & 11.9 & 0.029 & 311 & Native grassland \\
E02 & 21.0 & 0.043 & 327 & Native grassland \\
E18 & 17.9 & 0.009 & 433 & Arboreal \\
F02 & 18.6 & 0.125 & 972 & Native grassland \\
F10 & 17.3 & 0.193 & 68 & Native grassland \\
F18 & 9.4 & 0.162 & 477 & Native grassland \\
\hline
\end{tabular}

seasonal floodplain, the abundance of each species in the plots was plotted against the depth of the water column (Fig. 2). Based on the distribution of species in the depth gradient, three groups were observed. The first group consisted of the species Neofundulus parvipinnis, Laetacara dorsigera, Merodoras nheco, Trigonectes balzanii, Megalechis personatus, Lepthoplosternum pectorale and Rhamdia gr. quelen, which occur in shallow areas with a maximum depth of $25 \mathrm{~cm}$. The second group is made up of the species Serrasalmus maculatus, Metynnis mola, Markiana negripinnis, Chaetobranchopsis australis, Brachyhypopomus sp., Astyanax asuncionensis and Satanoperca pappaterra, occurring in plots with a depth above $45 \mathrm{~cm}$. For the third group the depth was not a limiting factor in the distribution, i.e., these species occurred throughout the sampled depth gradient (5 to $55 \mathrm{~cm}$ ). This group of species consisted of Hoplias malabaricus and Hoplerythrinus unitaeniatus, Hyphessobrycon elachys, Serrapinnus spp. and Aphyocharax anisitsi (Fig. 2).

The relationship between species richness (SR) in the plots and depth (DP), herbaceous plant biomass (HB) and distance from the source species (DC) was analyzed via a multiple regression analysis. The model explained $85 \%$ of the variation in the species richness $(\mathrm{SR}=-1.37+0.413 \mathrm{DP}+0.099 \mathrm{HB}+0.003 \mathrm{DC}$; $\left.\mathrm{r}^{2}=0.854 ; \mathrm{df}=3,17 ; \mathrm{p}<0.001\right)$. The richness of fish species was positively related to depth $(\mathrm{p}<0.001$, tol. $=0.878$; Fig. 3a) and distance from the colonizing source $(p=0.038$, tol. 0.951 ; Fig. $3 b)$, but not to herbaceous plant biomass ( $p=0.933$, tol. 0.853 ).

\section{The effect of exotic pasture on the ichthyofauna}

Since depth affected the composition of species in the assemblage, in order to evaluate the effect of the exotic pasture (type of vegetation), depth was considered a co-variable. The analysis indicated that the composition of species of fish in the area was not affected by the exotic pasture. This result was consistent both with quantitative (MANCOVA: Slope homogeneity test: Pillai trace $=0.478 ; \mathrm{F}_{6,30}=1.57 ; \mathrm{p}=0.190$; exotic pasture effect: Pillai trace $=0.554 ; \mathrm{F}_{6,34}=2.169, \mathrm{p}=0.071$ ), and qualitative (MANCOVA: Slope homogeneity test: Pillai trace $=0.234 ; \mathrm{F}_{6,30}=0.66 ; \mathrm{p}=0.68$; exotic pasture effect: Pillai trace $=0.281 ; \mathrm{F}_{6,34}=0.297 ; \mathrm{p}=0.488$ ) data. The number of species in the plots was also not affected by the replacement of native vegetation with exotic pasture in the sampled area (ANCOVA: Slope homogeneity test: $F=2.660 ; \mathrm{df}=2,13 ; \mathrm{p}=0.108$; distance from colonizing source effect: $F=3.437 ; \mathrm{df}=2,13 ; \mathrm{p}=0.063$; exotic pasture effect: $\mathrm{F}=1.062 ; \mathrm{df}=2,17 ; \mathrm{p}=0.368$ ).

\section{Discussion}

\section{Ichthyofauna}

Although most studies in South American rivers show the dominance of Characiformes and Siluriformes in relation to other orders, we did not find the same pattern in our study. Characiformes was the dominant order with regard to richness and abundance, but the order with the second highest number of species and abundance was Perciformes, and 
Table 2. List of the species captured in the 22 plots in Site of Long-Term Sampling (SLTS). N = number of individuals, SL= standard length $(\mathrm{mm}), \mathrm{SD}=$ standard deviation, $\mathrm{ML}=$ maximum length attained by the species based in Reis et al., 2003. * Individuals captured by gillnet. ** Individuals captured by throw trap. ${ }^{* *}$ Individuals captured in the two gear.

\begin{tabular}{|c|c|c|c|}
\hline Order/Family/Species & $\mathbf{N}$ & SL(SD) & ML \\
\hline \multicolumn{4}{|l|}{ Characiformes } \\
\hline \multicolumn{4}{|l|}{ Acestrorhynchidae } \\
\hline Aphyocharax anisitsi Eigenmann \& Kennedy, 1903 & 15 & 14(3) & $55^{* *}$ \\
\hline \multicolumn{4}{|l|}{ Anostomidae } \\
\hline Leporinus lacustris Amaral Campos, 1945 & 6 & $84(17)$ & $111^{*}$ \\
\hline Leporinus macrocephalus Garavello \& Britski, 1988 & 1 & 340 & $400^{*}$ \\
\hline \multicolumn{4}{|l|}{ Characidae } \\
\hline Aphyocharax nattereri (Steindachner, 1882) & 12 & 17(3) & $31 * *$ \\
\hline Aphyocharax rathbuni Eigenmann, 1907 & 1 & 24 & $26.9 * *$ \\
\hline Astyanax asuncionensis Géry, 1972 & 1 & 60 & $150^{*}$ \\
\hline Brycon hilarii (Valenciennes, 1850) & 5 & 148(37) & $415^{*}$ \\
\hline Bryconamericus exodon Eigenmann, 1907 & 6 & $22(3)$ & $57 * *$ \\
\hline Charax leticiae Lucena, 1987 & 1 & 38 & $100 * *$ \\
\hline Gymnocorymbus ternetzi (Boulenger, 1895) & 15 & $35(5)$ & $60 * * *$ \\
\hline Hyphessobrycon elachys Weitzman, 1984 & 171 & $15(2)$ & $17.9 * *$ \\
\hline Markiana nigripinnis (Perugia, 1891) & 1 & 81 & $104 *$ \\
\hline Metynnis mola Eigenmann \& Kennedy, 1903 & 2 & $34(2)$ & $150 * * *$ \\
\hline Moenkhausia dichroura (Kner, 1858) & 13 & $23(2)$ & $100 * *$ \\
\hline Poptella paraguayensis (Eigenmann, 1907) & 3 & $30(2)$ & $66^{* *}$ \\
\hline Psellogrammus kennedyi (Eigenmann, 1903) & 5 & $34(1)$ & $59 * *$ \\
\hline Serrasalmus maculatus Kner, 1858 & 1 & 62 & $210^{*}$ \\
\hline Serrapinnus microdon (Eigenmann, 1915) & 31 & $9(1)$ & $39.2 * *$ \\
\hline Serrapinnus spp. & 276 & 14(3) & $32.4 * *$ \\
\hline Triportheus sp. & 4 & $95(6)$ & $158^{*}$ \\
\hline \multicolumn{4}{|l|}{ Crenuchidae } \\
\hline Characidium aff. zebra Eigenmann, 1909 & 7 & $13(5)$ & $49^{* *}$ \\
\hline \multicolumn{4}{|l|}{ Curimatidae } \\
\hline Cyphocharax gillii (Eigenmann \& Kennedy, 1903) & 10 & 19(4) & $88 * *$ \\
\hline Steindachnerina brevipinna (Eigenmann \& Eigenmann, 1889) & 1 & 27 & $109 * *$ \\
\hline \multicolumn{4}{|l|}{ Erythrinidae } \\
\hline Hoplerythrinus unitaeniatus (Spix \& Agassiz, 1829) & 191 & 139(34) & $250^{*}$ \\
\hline Hoplias malabaricus (Bloch, 1794) & 28 & $131(57)$ & $490 * * *$ \\
\hline \multicolumn{4}{|l|}{ Lebiasinidae } \\
\hline Pyrrhulina australis Eigenmann \& Kennedy, 1903 & 35 & $18(5)$ & $50 * *$ \\
\hline \multicolumn{4}{|l|}{ Siluriformes } \\
\hline \multicolumn{4}{|l|}{ Auchenipteridae } \\
\hline Trachelyopterus striatulus (Steindachner, 1877) & 5 & $118(10)$ & $220^{*}$ \\
\hline \multicolumn{4}{|l|}{ Heptapteridae } \\
\hline Rhamdia gr. quelen (Quoy \& Gaimard, 1824) & 1 & 111 & $387^{*}$ \\
\hline \multicolumn{4}{|l|}{ Callichthyidae } \\
\hline Corydoras hastatus Eigenmann \& Eigenmann, 1888 & 1 & 13 & $24 * *$ \\
\hline Hoplosternum littorale (Hancock, 1828) & 40 & $92(11)$ & $158^{*}$ \\
\hline Lepthoplosternum pectorale (Boulenger, 1895) & 6 & $28(10)$ & $60.3 * *$ \\
\hline Megalechis thoracata (Ranzani, 1841) & 3 & $35(22)$ & $124 * *$ \\
\hline Doradidae & & & \\
\hline Merodoras nheco Higuchi, Birindelli, Sousa \& Britski, 2007 & 2 & $22(2)$ & $70^{* *}$ \\
\hline Perciformes & & & \\
\hline Cichlidae & & & \\
\hline Aequidens plagiozonatus Kullander, 1984 & 1 & 40 & $103 *$ \\
\hline Apistogramma borellii (Regan, 1906) & 10 & $16(3)$ & $39 * *$ \\
\hline Bujurquina vittata $($ Heckel, 1840$)$ & 2 & $39(37)$ & $70 * * *$ \\
\hline Chaetobranchopsis australis Eigenmann \& Ward, 1907 & 2 & $63(3)$ & $120^{*}$ \\
\hline Cichlasoma dimerus (Heckel, 1840) & 94 & $65(12)$ & $117^{* * *}$ \\
\hline Crenicichla lepidota Heckel, 1840 & 10 & $109(20)$ & $180^{*}$ \\
\hline Gymnogeophagus balzanii (Perugia, 1891) & 1 & 74 & $120^{*}$ \\
\hline Laetacara dorsigera (Heckel, 1840) & 63 & $18(6)$ & $45^{* *}$ \\
\hline Satanoperca pappaterra $($ Heckel, 1840$)$ & 1 & 78 & $174 *$ \\
\hline Cyprinodontiformes & & & \\
\hline Rivulidae & & & \\
\hline Neofundulus parvipinnis Costa, 1988 & 2 & $38(10)$ & $60 * *$ \\
\hline Plesiolebias glaucopterus (Costa \& Lacerda, 1988) & 3 & $20(11)$ & $30 * *$ \\
\hline Plesiolebias sp. & 1 & 16 & $30 * *$ \\
\hline Trigonectes balzanii (Perugia, 1891) & 2 & $74(46)$ & $120^{* * *}$ \\
\hline Gymnotiformes & & & \\
\hline Hypopomidae & & & \\
\hline Brachyhypopomus sp. & 2 & $108(8)$ & $180^{* *}$ \\
\hline Synbranchiformes & & & \\
\hline Synbranchidae & & & \\
\hline Synbranchus marmoratus Bloch, 1795 & 1 & 131 & $1500^{* *}$ \\
\hline
\end{tabular}




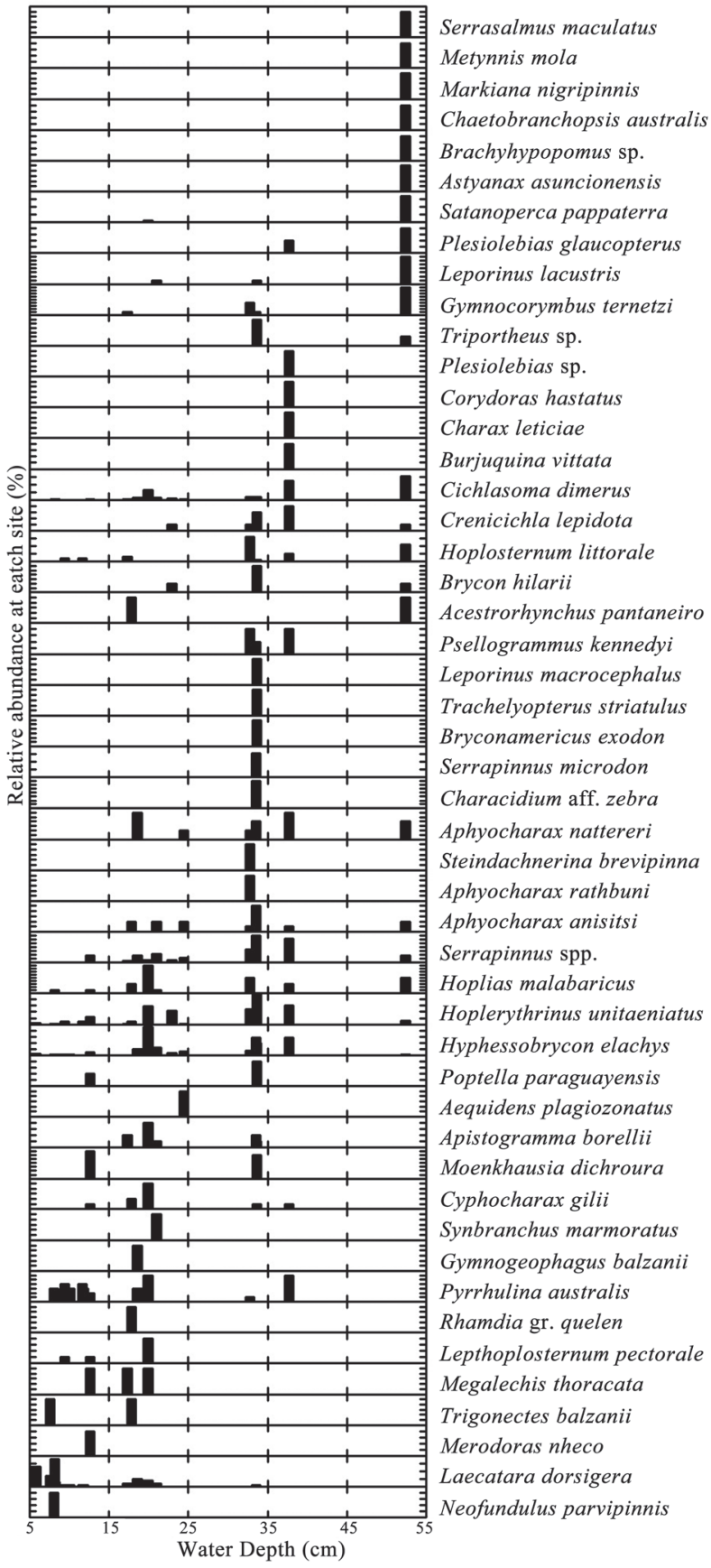

Fig. 2. Distribution of the relative abundance of the 49 species of fish captured in the 22 plots in Site of Long-Term Sampling (SLTS), related to the depth at each of the collection plots.

Siluriformes was the third most abundant order. A similar pattern was found by Pazin et al. (2006) in temporary ponds of Central Amazonia. The seasonal floodplain, made up mostly of shallow waters, is better exploited by Perciformes than Characiformes. The Perciformes are probably more adapted to this habitat because they are visually oriented fish and often associated with transparent water (Lowe-McConnell, 1999; Rodriguez \& Lewis, 1997), a predominant condition in the seasonal floodplains in the Pantanal. Another factor that may explain the dominance of Characiformes and Perciformes is the time of day in which the samples were caught. Most species of Siluriformes have nocturnal habits (Britiski et al., 1999). Therefore, samples carried out only during the day may have underestimated the number of species of this order that inhabit the seasonally flooded plains.

The dominance of small sized species in the seasonal floodplain is probably a result of the fact that small individuals are more successful in finding shelter and food in shallow areas, and are thus protected from predators that are abundant in deep open waters (Power, 1984; Jepsen, 1997; Pelicice et al., 2005). Individuals with a larger body size are more vulnerable to predation by birds and are less agile in shallow water (Power, 1984; Wills \& Magnuson, 2000). Thus, smaller species are probably more efficient at exploring the shallow environments in the floodplains.

Some studies have shown that the juveniles of species that have a reproductive migratory strategy use the seasonal floodplains for feeding and growth (Agostinho et al., 2001; Cunico et al., 2002). However, only five juvenile individuals of Brycon hilarii and an adult of Leporinus macrocephalus, two common migratory fishes, were captured in this study. Thus, we think these species use either lakes (Saint-Paul et al., 2000) or parts of the seasonal floodplain with greater depths than those used in our study, and they occasionally enter the flooded fields or forests in search of shelter, food or during migration.

\section{Relationship between the ichthyofauna and the environmental variables}

The influence of depth on the composition of species in a fish assemblage was also observed in streams (Power, 1984; Mendonça et al., 2005; Ferreira \& Casatti, 2006), in temporary environments (Kodric-Brown and Brown 1993; Baber et al., 2002; Pazin et al., 2006), in floodplain lakes (Rodriguez \& Lewis, 1997; Tejerina-Garro et al., 1998) and in secondary channels that join the lakes to the main river beds (Hoeinghaus et al., 2003).

There are two main mechanisms by which depth must influence the fish assemblages of temporary water bodies in the area. The first is that variation in the depth of the water column between plots reflects the variation in the hydroperiod. The greater the depth, the greater the hydroperiod of the plot and, therefore, the greater the time available for the processes of extinction and colonization to reach a balance and for the richness and composition of species in the assemblage to stabilize (MacArthur \& Wilson, 1967). Even though very little is known about the processes of colonization in tropical ecosystems (Granado-Lorêncio et al., 2005), as well as temporary environments, it is possible to deduce that the deepest areas are more likely to be colonized, since they remain flooded for longer periods (Barber et al., 2002).

The second mechanism reflects the paths chosen by the organisms and their ability for dispersal and colonizing the newly flooded plain. The assemblages of the temporary water bodies are assembled during floods and disassembled during the ebb period (Arrington et al., 2005). The recently 

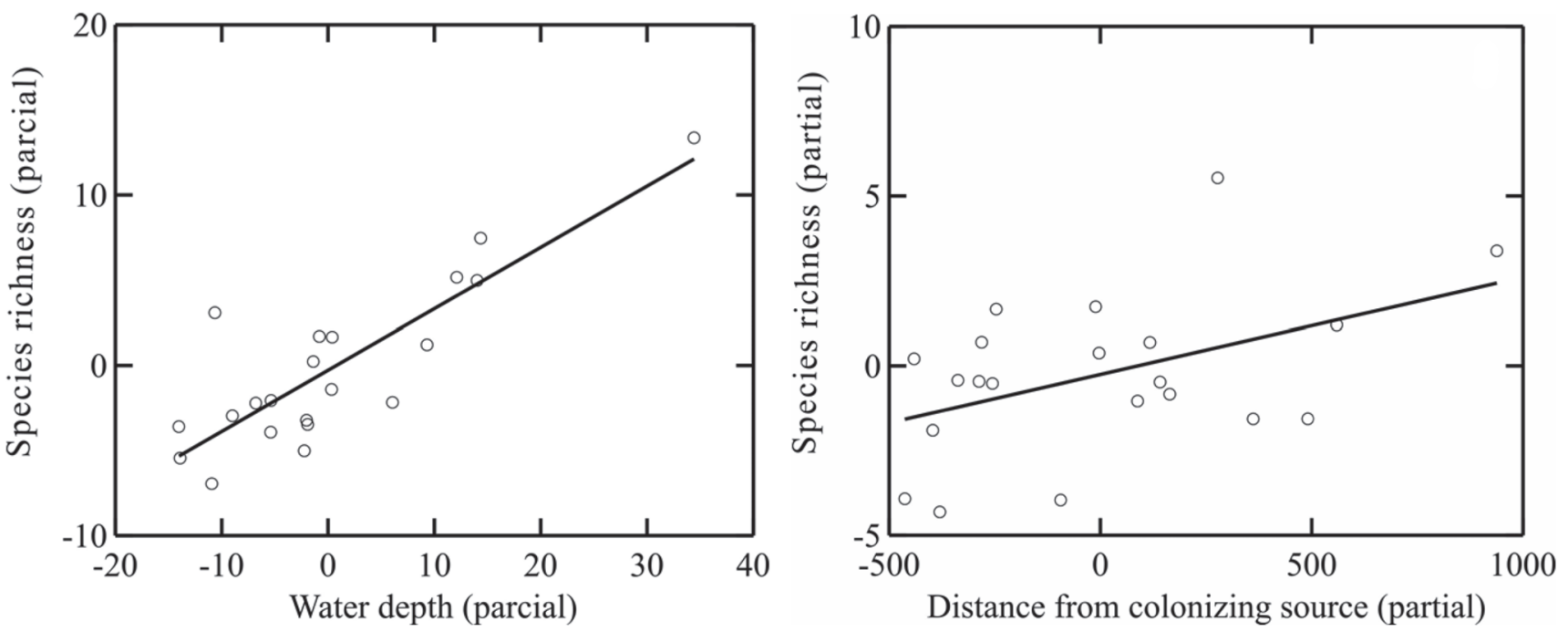

Fig. 3. Partial regressions testing the effects of water depth (left) and distance from colonizing source (right) on fish species richness collected in 22 plots in Site of Long-Term Sampling (SLTS). Only statistically significant relationships are shown.

formed temporary environments are colonized by individuals from the permanent water bodies. The paths used for the colonization of the floodplains are complex and influenced by subtle variations in the topography of the land and by the morphological characteristics of each species. Thus, deeper areas that are the first to receive water from the floods are virtually closer to permanent water bodies than shallow areas, which will only become available to aquatic organisms as the flood advances.

An alternative hypothesis is that the relationship between depth and richness reflect the relationship between species and area, in this case species richness and volume.

Deeper environments may have a greater complexity of habitats, supporting a larger number of fish species (Eadie $e t$ al., 1986, Pianka, 1994), due to the occupation of the water column in a stratified way (Mayo \& Jackson, 2006). Moreover, the pressure of predation by water birds is potentially smaller, due to the lower capture efficiency in deeper areas (Power, 1984). However, a positive relationship between richness and distance from the source of colonization may be linked to the size of the individuals who occupy the seasonally flooded plains. The small body size and morphological adaptations of each species allow the dispersal of individuals to sites that are distant from the permanent water bodies thereby reducing the predation pressure by aquatic predators that are living in these regions.

\section{The effect of exotic pasture on the ichthyofauna}

Contrary to our expectations, the conversion of fields with native pasture to fields with exotic pasture did not influence the fish assemblage in the study area. Two non-exclusive factors may be responsible for the pattern found in this study. First the effect of landscape - the four plots of exotic pasture sampled are small patches located within a natural landscape (trees and natural grasslands), in which species have a wide distribution. Thus, the species may access the exotic pasture with the same ease at which they can access the native vegetation, which could be why we did not find any effect of changing the landscape in fish assemblages within the studied scale. Second, the effect of structural complexity - despite the conversion of native vegetation to exotic pasture leading to a reduction in the diversity of herbaceous species in natural grasslands, the opposite occurs when sites with woody vegetation are converted to exotic pasture. Although exotic, B. humidicola may have a similar structural complexity to native species (Dibble et al., 1996, Dibble et al., 2006; Pelicice et al., 2008), so sites with exotic pasture may have a similar habitat structure to the areas with natural vegetation.

In summary, the response of the fish community to depth shows the importance that different habitats have for species that live in the seasonally flooded plain and the dependence of the species to specific depths. As the depth reflects the intensity of flooding, flood control in floodplain rivers can drastically affect the dynamics of fish assemblages in these systems, consequently altering the aquatic biota. Different from other systems in the Pantanal, the replacement of natural vegetation by exotic pasture apparently did not affect the fish assemblage, however, we emphasize that the number of environments with exotic plants in this study was low and that studies in landscapes dominated by pastures are necessary for a better assessment of their affect on the community.

\section{Acknowledgements}

We thank Jansen Zuanon and Eduardo Venticinque, for constructive comments on an initial draft. The two anonymous referees have improved the quality of this paper. Specimens were collected under legal authority of permits issued by the Secretaria de Meio Ambiente do Estado de Mato Grosso. This research was supported by the Pantanal Research Center (CPP), Ministério da Ciência e Tecnologia, and Program 
LTER sponsored by Conselho Nacional de Desenvolvimento Científico e Tecnológico (CNPq), Brazil. Izaias Médice Fernandes acknowledges a master scholarship from Coordenação de Aperfeiçoamento de Pessoal de Nível Superior(CAPES), Brazil.

\section{Literature Cited}

Adámoli, J. 1982. O pantanal e suas relações fitogeográficas com os cerrados. Discussão sobre o conceito "Complexo do Pantanal". Pp. 109-119. In: Congresso Nacional de Botânica. Teresina-PI. Sociedade Brasileira de Botânica.

Agostinho, A. A., L. C. Gomes \& M. Zalewski. 2001. The importance of floodplains for the dynamics of fish communities of the upper river Paraná. Ecohydrology \& hydrobiology, 1:209-217.

Anderson, M. J. \& T. J. Willis. 2003. Canonical analysis of principal coordinates: a useful method of constrained ordination for ecology. Ecology, 84: 511-525.

Angermeier, P. L. \& I. J. Schlosser. 1989. Species-area relationships for stream fishes. Ecology, 70(5): 1450-1462.

Arrington, D. A. \& K. O. Winemiller. 2003. Diel changeover in sandbank fish assemblages in a Neotropical floodplain river. Journal of Fish Biology, 63: 442-459.

Arrington, D. A., K. O. Winemiller \& C. A. Layman. 2005. Community assembly at the patch scale in a species rich tropical river. Oecologia, 144: 157-167.

Baber, J. M., D. L. Childers, K. J. Babbitt \& D. H. Anderson. 2002. Controls on fish distribution and abundance in temporary wetlands. Canadian Journal of Fisheries and Aquatic Sciences, 59: 1441-1450.

Barko, V. A., D. P. Herzog \& T. O. Connell. 2006. Response of fishes to floodplain connectivity during and following a 500year flood event in the unipounded upper Mississipi River. Wetlands, 26(1): 244-257.

Britski, H. A., K. Z. S. Silimon \& B. S. Lopes. 1999. Peixes do Pantanal: manual de identificação. Brasília: EMBRAPA. 184p.

Costa, F. R. C., W. E. Magnusson \& R. Luizao. 2005. Mesoscale distribuition patterns of Amazonian understorey herbs in relation to topography, soil and watersheds. Journal of Ecology, 93: 863-878.

Cunico, A. M., W. J. Graça, S. Veríssimo \& L. M. Bini. 2002. Influência do nível hidrológico sobre a assembleia de peixes em lagoa sazonalmente isolada da planície de inundação do alto rio Paraná. Acta Scientiarum, 24(2): 386-389.

Dibble, E. D, K. J. Killgore \& G. O. Dick. 1996. Measurement of Plant architecture in seven aquatic plants. Journal of Freshwater Ecology, 11(3): 311-318.

Dibble, E. D, S. M. Thomaz \& A. A. Padial. 2006. spatial complexity measured at a multi-scale in three aquatic plant species. Journal of Freshwater Ecology, 21(2): 239-247.

Eadie, J. M., A. T. Hurly, R. D. Montgomerie \& K. L. Teather. 1986. Lakes and rivers as islands: species-area relationships in the fish faunas of Ontario. Environmental Biology of Fishes, 15(2): 81-89.

Faith, D. P., P. R. Minchin \& L. Belbin. 1987. Compositional dissimilarity as a robust measure of ecological distance. Vegetatio, 69: 57-68.

Ferreira, C. P. \& L. Casatti. 2006. Influência da estrutura do hábitat sobre a ictiofauna de um riacho de uma micro-bacia de pastagem, São Paulo, Brasil. Revista Brasileira de Zoologia, 23(3): 624-651.
Granado-Lorencio, C., R. M. A. Lima \& J. Lobón-Cerviá. 2005. Abundance - distribution relationships in fish assembly of the Amazonas floodplain lakes. Ecography, 28: 515-520.

Hamilton, S. K., S. J. Sippel \& J. M. Melack. 1996. Inundation patterns in the Pantanal wetland of South America determined from passive microwave remote sensing. Archiv Fur Hydrobiologie, 137: 1-23.

Hejda, M., P. Pysek \& V. Jarosík. 2009. Impact of invasive plants on the species richness, diversity and composition of invaded communities. Journal of Ecology, 97: 393-403.

Hoeinghaus, D. J., C. A. Layman, D. A. Arrington \& K. O. Winemiller. 2003. Spatiotemporal variation in fish assemblage structure in tropical floodplain creeks. Environmental Biology of Fishes, 67: 379-387.

Hoffmann, W. A. \& M. Haridasan. 2008. The invasive grass, Melinis minutiora, inhibits tree regeneration in a Neotropical savanna. Austral Ecology, 33: 29-36.

IBGE. 1992. Manual técnico da vegetação brasileira (IBGE, ed.), Rio de Janeiro. 92p.

Jepsen, D. B. 1997. Fish species diversity in sand bank habitats of a neotropical river. Environmental Biology of Fishes, 49: 449-460.

Jordan, F., S. Coyne \& J. C. Trexler.1997. Sampling fishes in vegetated habitats: effects of habitat structure on sampling characteristics of the $1 \mathrm{~m}^{2}$ Throw Trap. Transactions of the American Fisheries Society, 126: 1012-1020.

Junk, W. J. 2000. Neotropical Floodplains: A Continental-Wide view. Pp. 5-26. In: Junk W. J., J. J. Ohly, M. T. F. Piedade, M. G. M Soares (Eds.) The central Amazon Floodplain: Actual Use and Options for a Sustainable Management. Leiden: Backhuys Publishers.

Junk, W. J., P. B. Bayley \& R. S. Sparks. 1989. The flood pulse concept in river - floodplain systems. Pp. 110-127. In: Dodge D. P. (Ed.) Proceedings of the International Larger River Symposium. (LARS). Canadian Journal of Fisheries and Aquatic Sciences, 106.

Kinupp, V. F. \& W. E. Magnusson. 2005. Spatial patterns in the understorey shrub genus Psychotria in central Amazonia: effects of distance and topography. Journal of Tropical Ecology, 21: 363-374.

Kodric-Brown, A. \& J. H. Brown. 1993. Highly structured fish communities in australian desert springs. Ecology, 74(6): 1847-1855.

Lapointe, N. W. R., L. D. Corrum \& N. E. Mandrak. 2006. A comparison of methods for sampling fish diversity in shallow offshore waters of large rivers. North American Journal of Fisheries Management, 26: 503-513.

Latini, A. O. \& M. Petrere Júnior. 2004. Reduction of a native fish fauna by alien species: an example from Brazilian freshwater tropical lakes. Fisheries Management and Ecology, 11: 71-79.

Legendre, P. \& L. Legendre. 1998. Numerical ecology. Elsevier, Amsterdam. 853p.

Li, R. Y. \& F. P. Gelwick. 2005. The relationship of environmental factors to spatial and temporal variation of fish assemblages in a floodplain river in Texas, USA. Ecology of Freshwater_Fish, 14(4): 319-330.

Lowe-Mcconnell, R. H. 1999. Estudos Ecológicos de Comunidades de Peixes Tropicais. Editora da Universidade de São Paulo, São Paulo, Brasil. 534p.

MacArthur, R. H \& E. O. Wilson. 1967. The Theory of Island Biogeography. Princeton University Press, Princeton. 224p.

Magnusson, W. E., A. P. Lima, R. Luizão, F. Luizão, F. R. C. Costa, C. V. Castilho \& V. F. Kinupp. 2005. RAPELD: a modification of the Gentry method for biodiversity surveys in long-term ecological research sites. Biota Neotropica, 5(2): 19-24. 
Mayo, J. S. \& D. A. Jackson. 2006. Quantifying littoral vertical habitat structure and fish community associations using underwater visual census. Environmental Biology of Fishes, 75: 395-407.

Mendonça, F. P., W. E. Magnusson \& J. Zuanon. 2005. Relationship between habitat characteristics and fish assemblages in small streams of Central Amazonia. Copeia, 2005(4): 750-763.

Mourão, G., M. D. Oliveira, D. F. Calheiros, C. R. Padovani, E. J. Marques \& M. Uetanabaro. 2002. O Pantanal Mato-grossense. Pp. 29-47 In: Seedliger U., C. Cordazzo \& F. A. R. Barbosa (Eds.). Os sites e o programa brasileiro de pesquisas ecológicas de longa duração. Conselho Nacional de Desenvolvimento Científico e Tecnológico, Belo Horizonte, Brasil.

Pazin, V. F. V., W. E. Magnusson, J. Zuanon \& F. P. Mendonça. 2006. Fish assemblages in temporary ponds adjacent to 'terra firme' streams in Central Amazonia. Freshwater Biology, 51: 1025-1037.

PCPAB - Plano de Conservação da Bacia do Alto Paraguai. 1997. Diagnóstico dos meios físico e biótico. Projeto Pantanal, Programa Nacional do Meio Ambiente. Meio físico, V. II, Tomo I, Brasília: PNMA.

Pelicice, F. M. \& A. A. Agostinho. 2009. Fish fauna destruction after the introduction of a non-native predator (Cichla kelberi) in a Neotropical Reservoir. Biological Invasions, 11: 1789-1801.

Pelicice, F. M., A. A. Agostinho \& S. M. Thomaz. 2005. Fish assemblages associated with Egeria in a tropical reservoir: investigating the effects of plant biomass and diel period. Acta Oecologica, 27:9-16.

Pelicice, F. M., S. M. Thomaz \& A. A. Agostinho. 2008. Simple relationships to predict attributes of fish assemblages in patches of submerged macrophytes. Neotropical Ichthyology, 6(4): 543-550.

Penha, J. M. F., C. J. da Silva \& I. Bianchini-Júnior. 1999. Productivity of the aquatic macrophyte Pontederia lanceolata Nutt. (Pontederiaceae) on oodplains of the Pantanal Mato-grossense, Brazil. Wetlands Ecology and Management, 7: 155-163.

Petry, A. C., A. A. Agostinho \& L. C. Gomes. 2003. Fish assemblages of tropical floodplain lagoons: exploring the role of connectivity in a dry year. Neotropical Ichthyology, 1: 111-119.

Pianka, E. R. 1994. Evolutionary Ecology. 5. ed. New York: Harper Collins. 486p.

Power, M. E. 1984. Depth distributions of armored catfish predatorinduced resource avoidance. Ecology, 65(2): 523-528.
Prance, G. T. \& G. B. Schaller. 1982. Preliminary study of some vegetation types of the Pantanal, Mato Grosso, Brazil. Brittonia, 34(2): 228-251,

Rebellato, L. \& C. Nunes da Cunha. 2005. Efeito do "fluxo sazonal mínimo da inundação" sobre a composição e estrutura de um campo inundável no Pantanal de Poconé, MT, Brasil. Acta Botânica Brasilica, 19(4): 789-799.

Reis, R. E., O. Kullander \& C. J. Ferraris Jr. 2003. Check List of the Freswater Fishes of South and Central America. Porto Alegre, Edipucrs. 742p.

Rodríguez, M. A. \& M. L. Lewis. 1997. Structure of fish assemblages along environmental gradients in floodplain lakes of the Orinoco river. Ecological Monographs, 67(1): 109-128.

Saint-Paul, U., J. Zuanon, M. A. V. Correa, M. Garcia, N. N. Fabre, U. Berger \& W. J. Junk. 2000. Fish communities in central Amazonian white- and black water floodplains. Environmental Biology of Fishes, 57: 235-250.

Súarez, Y. R., M. Petrere-Jr \& A. C. Catella. 2001. Factors determining the structure of fish comunities in Pantanal lagoons (MS, Brazil). Fisheries Management and Ecology, 8: 173-186.

Teixeira-de-Mello, F., M. Meerhoff, Z. Pekcan-Hekim \& E. Jeppesen. 2009. Substantial differences in littoral fish community structure and dynamics in subtropical and temperate shallow lakes. Freshwater Biology, 54: 1202-1215.

Tejerina-Garro, F. L., R. Fortin \& M. A. Rodriguez. 1998. Fish community structure in relation to enviromental variation in floodplain lakes of the Araguaia River, Amazon Basin. Environmental Biology of Fishes, 51: 399-410.

Thomaz, S. M., L. M. Bini \& R. L. Bozelli. 2007. Floods increase similarity among aquatic habitats in river-floodplain systems. Hydrobiologia, 579: 1-13.

Ward, J. V., K. Tockner, D. B. Arscott \& C. Klaret. 2002. Riverine landscape diversity. Freshwater Biology, 47: 517-539.

Weaver, M. J., J. J. Magnuson \& M. K. Clayton. 1993. Analyses for differentiating littoral fish assemblages with catch data from multiple sampling gears. Transactions of the American Fisheries Society, 122: 1111-1119.

Weaver, M. J., J. J. Magnuson \& M. K. Clayton. 1997. Distribution of littoral fishes in structurally complex macrophytes. Canadian Journal of Fisheries and Aquatic Sciences, 54: 2277-2289.

Willis, T. V. \& J. J. Magnuson. 2000. Patterns in fish species composition across the interface between streams and lakes. Canadian Journal of Fisheries and Aquatic Sciences, 57: 1042-1052.

Accepted January 24, 2010 Published June 25, 2010 